\title{
Maternal-calf relationships and their influence on calves up to 120 days
}

\author{
Relaciones materno-filiales y su influencia en terneros hasta los \\ 120 días de edad
}

\author{
Emanoela Souza-Conde AL, ${ }^{1}$ M.Sc, María V. Andrea, ${ }^{1 *}$ Ph.D, Marcy Conde $\mathrm{L}^{1}{ }^{1}$ Ing Pesca, Jesus \\ Delgado-Mendez, ${ }^{1}$ Ph.D, Fagner C. Souza, ${ }^{1}$ Ing Agr, Mateus Paranhos da Costa JR, ${ }^{2}$ Ph.D, \\ Thereza CB de Bittencourt dos SC, ${ }^{3}$ Ph.D, Kaliane de Oliveira N, ${ }^{1}$ M.Sc.
}

\begin{abstract}
${ }^{1}$ Universidade Federal do Recôncavo da Bahia. Centro de Ciencias Agrarias, Ambientales y Biológicas. Rua Rui Barbosa, 710, Centro. Cruz das Almas- BA, Brasil. ²Departamento de Zootecnia, Faculdade de Ciências Agrárias e Veterinárias, UNESP -Via de Acesso Prof.Paulo Donato Castellane s/n. Jaboticabal, SP, Brasil. ${ }^{3}$ Universidade Federal da Bahia - UFBA. Escola de Medicina Veterinária. Av. Adhemar de Barros, 500 - Ondina - Salvador-BA, Brasil. *Correspondência: mvander@ufrb.edu.br.
\end{abstract}

Received: October 2013; Accepted: June 2014.

\begin{abstract}
Objectives. To research parental behavior and measure the weight of Nelore and Guzerat calves up to 120 days of age, collecting data from birth up to the first lactation. Materials and methods. Seven different corporal positions were considered to obtain specific data for each of the following categories: time to stand (TP), time to intend to feed after standing (TPTM), weight at birth (PN), weight at 120 days (P120), and time in contact with the calf (TCC). Additionally, independent variables were also evaluated, organized by class: weight at birth (CPN), number of calvings (CNP), order of calving in relation with the herd (CLPR), time of calving (CHP), and finally, hindering to feed (CTAT). Results. There was a significant result in favor of the Nelore race over the Guzerat race. The statistical averages for Nelore and Guzerat were: Time to stand averaged 71 and 153 minutes; time to intend to feed after standing, 39 minutes for Nelore and of 114 minutes for Guzerat. For variable weight at 120 days, Nelore reached an average of $122 \mathrm{~kg}$, and Guzerat $109 \mathrm{~kg}$. For the time in contact with the calf variable there was no significant variance between races. Conclusions. Results showed the superiority of the Nelore race, considering it better adapted to local environmental conditions.
\end{abstract}

Key words: Behavior, calves, suckling, well being (Source: $C A B$ ).

\section{RESUMEN}

Objetivo. Investigar el comportamiento materno y observar su influencia en el peso de los terneros de las razas Nelore y Guzerat hasta los 120 días de edad, evaluándolos desde su nacimiento hasta el primer amamantamient. Materiales y métodos. Se consideraron siete posturas corporales diferentes, las cuales fueron usadas para obtener las observaciones específicas en cada una de las siguientes categorías: Tiempo para ponerse de pie (TP), Tiempo para intentar lactar después de ponerse de pie (TPTM), peso al nacer (PN), peso a los 120 días (P120) y tiempo de contacto con la cría (TCC). Se evaluaron las variables independientes, organizadas en clases: peso al nacer (CPN); número de partos (CNP); orden del parto en relación al rebaño (CLPR); hora del parto (CHP) y obstaculización de mamada (CTAT). Resultados. Se obtuvo un mejor resultado en los terneros de la raza Nelore en relación a los 
de la raza Guzerat. Los promedios estadísticos para Nelore y Guzerat fueron los siguientes: TP con media de 71 y 153 minutos; TPTM de 39 y 114 minutos; P120 con 122 kg para terneros Nelore y 109 $\mathrm{kg}$ para los de la raza Guzerat. La variable TCC no obtuvo una diferencia significativa entre las razas. Conclusiones. Los resultados demuestran una superioridad para animales de la raza Nelore, lo que permite inferir que poseen una mejor adaptación a las condiciones ambientales locales.

Palabras clave: Amamantamiento, bienestar, comportamiento, terneros (Fuente: $C A B$ ).

\section{INTRODUCTION}

The birth process is a dynamic event and is fundamentally important to mammals since it guarantees the continuity of the species (1). Maternal behavior of different species decisively affects the well-being and development of newborn animals. According to Paranhos et al (2) and Hötzel and Machado Filho (1), changes in maternal behavior are synchronized with the development of calves and with feedback between mother and calf that provokes regularity of a determined behavior. Much of this behavior is activated during the last stages of pregnancy or at the moment of calving.

According to Toledo (3) and Schmidek et al (4), an adequate analysis is necessary in order to evaluate the behavioral characteristics related to maternal abilities and a satisfactory lactation. Two aspects are outstanding: the survival of the calf (including the capacity of the cow to wean a calf every year) and the production of milk (considering production and sanitary characteristics). However, there are controversies over what should really be considered. Regarding maternal ability, two points stand out: the ethological evaluation and the potential growth of the calf.

Thus, the phases when the calf is still under maternal care and the later interruption of this relationship at weaning are considered highly important for the future development of the calf. According to Paranhos da Costa et al (5), behavioral patterns of cows and calves during the prenatal period can be associated with survival and the future development of calves and maternal performance of cows in later calvings. The above author mentions the fact that some calves do not feed during the first six hours of life, and that this becomes significant when the percentage of incidence of this event is linked to survival rate, incurring also additional handling difficulties such as artificial lactation, calf adoption, and cow retention to be able to apply forced lactation.

With the objective of comparing maternal behavior of bovine breeds in the semiarid region of Bahía as well as observing its influence on

\section{INTRODUCCIÓN}

El proceso de nacimiento es un evento dinámico y de importancia fundamental en la vida de los mamíferos, garantizando la continuidad de la especie (1). El comportamiento materno de diferentes especies influye decisivamente sobre el bienestar y el desarrollo de los animales recién nacidos. De acuerdo con Paranhos et al (2) y Hötzel y Machado Filho (1), los cambios en el comportamiento materno están sincronizados con el desarrollo de las crías, existiendo un feedback en la relación madre-cría que provoca la regularidad de un determinado comportamiento. Muchos de estos comportamientos son activados en las últimas etapas de la gestación o en el exacto momento del nacimiento de la prole.

De acuerdo con Toledo (3) y Schmidek et al (4) es necesario un análisis adecuado, con el fin de evaluar las características comportamentales relacionadas a las habilidades maternas y a una lactancia satisfactoria. Dos aspectos llaman la atención: la supervivencia del ternero (incluyendo la capacidad de la vaca de destetar un ternero por año) y la producción de leche (considerando características productivas y sanitarias). Sin embargo, hay controversias sobre lo que realmente debería ser considerado. Dentro de los aspectos de habilidad materna, se destacan dos puntos: la evaluación etológica y el potencial de crecimiento del ternero.

De esta manera, las fases en las cuales el ternero todavía se encuentra sobre los cuidados maternos y la posterior interrupción de esta relación en el destete, son consideradas de gran importancia para el futuro desarrollo del ternero. Según Paranhos da Costa et al (5) los padrones comportamentales de vacas y terneros durante el período prenatal pueden estar asociados a la supervivencia, al futuro desarrollo de los terneros y al desempeño materno de las vacas en partos posteriores. Dicho autor menciona sobre el hecho de que los terneros no sean amamantados en las primeras seis horas de vida y de cómo esto asume significativa importancia, una vez que el porcentaje de incidencia de este evento está asociado a la tasa de supervivencia, ocasionando también dificultades extras en el manejo, tales como lactación artificial, adopción de terneros y contención de la vaca para realización de amamantamiento forzado. 
weight at 120 days, calvings of Nelore and Guzerat cows were evaluated on a specific property in the abovementioned state of Brazil under local climactic conditions.

\section{MATERIALS AND METHODS}

Study location. This study took place at the Hacienda Soraya, in Serra Preta municipality in the Brazilian meso-region of Centro Norte Bahiano, the Feira de Santana micro-region, with semiarid climactic characteristics, $161 \mathrm{~km}$ from the capital city, Salvador. The municipality has an extension of $540.9 \mathrm{~km}^{2}$, and the coordinates are: latitude $12^{\circ} 11^{\prime} 15^{\prime \prime} \mathrm{S}$, longitude $39^{\circ} 18^{\prime} 45^{\prime \prime} \mathrm{W}$ and altitude $311 \mathrm{~m}$.

Samples. Two groups of Zebu animals were defined: 9 Nelore cows and 9 Guzerat cows. The animals were handled in a maternity paddock (2 ha) with "urucroa" (Urochloa moçambisensis) forage pasture under a continuous feed system close to the corral. The animals were taken to the paddock 15 to 20 days before giving birth. Births occurred in the period from March to July.

The Nelore and Guzerat breeds are part of the Nelore Brazil and Guzerat Brazil Programs.

General description. In order to measure animal behavior, direct observations of the activities of the cows and calves took place during the first hours after calving. Calvings that took place from 4 hours until 23 hours were observed, and observation started when cows presented characteristics that indicated imminent birth. Data began to be recorded after the complete expulsion of the calf, observing body posture and activities of both the cow and the calf. Focal samples and continuous recording was done in order to be able to record observations on events occurring in a short space of time.

Following the model adapted from the etiological chart "Etograma de Trabalho" (6), the following behavioral categories for cows and calves were defined in relation to body postures:

Lying down. The animal was not supported by any body part, whether on the side or ventral; Standing. The animal was supported on four legs;

In circular movement. Moving around its own body, staying in the same place;

Move. When the animal moved its legs and left the place it occupied before.

The following categories were defined specifically with relation to cows in post-partum activities:
Con el objetivo de comparar razas bovinas en lo que respecta al comportamiento maternal en la región semiárida de Bahía, así como observar su influencia en el peso a los 120 días de edad, fueron evaluados partos de vacas Nelore y Guzerat, en una determinada propiedad del mencionado estado brasileño, con condiciones climáticas locales.

\section{MATERIALES Y MÉTODOS}

Lugar de estudio. Este trabajo fue realizado en la Hacienda Soraya, situada en el municipio de Serra Preta, insertada en la meso-región brasileña del Centro Norte Bahiano, micro-región de Feira de Santana, con características climáticas de semiárido, a $161 \mathrm{~km}$ de la ciudad capital Salvador. El municipio tiene una superficie de $540.9 \mathrm{~km}^{2}$, con latitud de $12^{\circ} 11^{\prime} 15^{\prime \prime S}$, longitud de 39018'45"W y altitud de $311 \mathrm{~m}$.

Muestras. Fueron definidos dos grupos de animales de razas cebúes: 9 vacas Nelore y 9 vacas Guzerat. Los animales fueron manejados en el potrero de maternidad ( $2 \mathrm{ha}$ ) compuesto de pastura de forraje "urucroa" (Urochloa moçambisensis) bajo el sistema de pasto continuo, próximo al corral. Dichos animales fueron conducidos al potrero alrededor de 15 a 20 días antes del parto. Las pariciones ocurrieron en el período de marzo a julio.

El plantel de las razas Nelore y Guzerat forma parte de los Programas Nelore Brasil y Guzerat Brasil.

Descripción general. Con el objetivo de medir el comportamiento de los animales, fueron realizadas observaciones directas a las actividades de vacas y terneros durante las primeras horas subsiguientes al parto. Fueron acompañados los partos que ocurrieron desde las $4 \mathrm{~h}$ hasta las $23 \mathrm{~h}$. La observación fue iniciada cuando la vaca presentó características que indicaban inminencia de parto. El registro de los datos se inició después de la expulsión completa del ternero, observándose la postura corporal y las actividades desarrolladas, tanto por la vaca como por el ternero. Se utilizó el proceso de muestra focal y registro continuo, con la finalidad de facilitar las observaciones que ocurrían en un corto espacio de tiempo.

Siguiendo el modelo adaptado del gráfico etológico o "Etograma de Trabalho" (6), fueron definidas las siguientes categorías comportamentales para vacas y terneros, con relación a sus posturas corporales:

Acostada. El animal no se apoyaba en ninguno de sus miembros, pudiendo estar en decúbito lateral o ventral;

Parada. El animal se encontraba apoyado sobre los cuatro miembros; 
Contact with calves. Activities consisting of smelling, licking and pushing calves, in direct contact;

Without apparent activity. When the cow is motionless, without any apparent movement;

Feeding difficulties. Activities that constitute impeding access of the calf to the udder; backing up, walking in circles, kicking and butting the calf.

Regarding calf activities, the following categories were also considered:

Lying on side. When in lateral lying position; Lying down. When in sternal position;

First movement. When it moved its head, turning to get into the sternal position;

Standing. Time taken to stand up;

Time the calf takes to begin to feed.

Trying to feed. When the calf found the udder and tried to attach itself;

Lactation. When the calf had the udder in its mouth, sucking.

Recording was terminated immediately after the calf was able to start sucking or, if this did not occur, after five hours of observation. Cases that needed help (two Guzerat cows) were not included in the data recorded.

After field activities, data was recorded and variables calculated. When the calf was not able to feed, when it could not get up within six hours, 315 minutes for latencies (standing and trying to feed) was attributed, which was defined by the total observation time plus 15 more minutes. When these behavioral categories took more than 5 hours of observation, the maximum observation time value was assumed as representative of latency to stand up (TP), as well as latency to attempt feeding after standing up (TPTM).

Statistical analysis. Two sets of variables were defined: one for calf behavior and weight gain after 120 days, and the other for behavior of cows when with calves.

Four variables were considered for calves:

Time to stand up (TP). Time that the calf took from birth until standing on its four legs, firmly or unbalanced;

Time to try to feed after standing up (TPTM). Defined as the time the calf takes after standing up to attempt attaching itself to the udder;

Weight at birth (PN). Weight of the calf the day following birth;

Weight at 120 days (P120). Weight of the calf at 120 days.
En movimiento circular. Haciendo movimientos alrededor de su propio cuerpo, permaneciendo en el mismo local;

Desplazamiento. Cuando el animal movía las patas de lugar y salía del lugar que ocupaba anteriormente.

Específicamente en las vacas fueron definidas las siguientes categorías, relacionadas con las actividades post parto:

Contacto con la cría. Actividades que consistieron en oler, lamer y empujar a la cría, estando en contacto directo;

Sin actividad aparente. Cuando la vaca se encontraba quieta, sin ningún movimiento aparente;

Perturbación del amamantamiento. Actividades que consistieron en impedir el acceso del ternero a la ubre, con movimientos de retroceder, andar en círculos, dar patadas y cabezazos a la cría.

Con respecto a las actividades de los terneros, fueron consideradas también las siguientes categorías:

Acostado. Cuando se encontraba en posición de decúbito lateral;

Echado. Cuando estaba en decúbito esternal;

Primer movimiento. Cuando movía la cabeza, girando para quedarse en posición de decúbito esternal;

De pie. Tiempo que ha demorado para ponerse de pie;

Tiempo que el ternero ha llevado para comenzar a mamar.

Intento de mamar. Cuando el ternero encontraba la ubre e intentaba prenderse de una de ellas; Lactación. Cuando el ternero estaba con la ubre en la boca, realizando movimientos de succión.

Los registros terminaron inmediatamente después de que el ternero consiguió realizar su primera mamada o cuando ésta no ocurría, después de cinco horas de observación. Los casos que necesitaron de ayuda (dos vacas de la raza Guzerat) no integraron el registro de datos.

Al final de las actividades de campo, los datos fueron registrados y las variables calculadas. Cuando el ternero no consiguió mamar, o sea, no consiguió levantarse en el lapso de seis horas, se le atribuyó el valor de 315 minutos para las latencias (ponerse de pie e intentar mamar) lo cual fue definido por el tiempo total de observación, sumándole 15 minutos más. Cuando estas categorías de comportamiento tuvieron un tiempo superior a las 5 horas de observación, fue asumido el valor máximo de tiempo de observación como 
For cows, the variable was:

Contact time with the calf (TCC). Defined as the percentage of time that the cow was in contact with the calf in relation to total observation time in activities such as licking, smelling and touching the calf, caring for and encouraging calf movement.

Values obtained in the field were grouped into classes (from 1 to 6 , differentially) from which the following independent variables were created:

CPN (calving weight class): 1 - calves from 25 to $30 \mathrm{~kg}, 2$ from 31 to $35 \mathrm{~kg}$ and 3 from 36 to $40 \mathrm{~kg}$;

CNP (calving number class): 1 - first calving, 2 - second calving y 3 - third calving or more; CLPR (calving location in relation to herd class): 1 - for calvings 0 to 10 meters from the flock, 2 - for calvings 11 to $30 \mathrm{~m}$ and 3 - for calvings greater than $30 \mathrm{~m}$;

CHP (hour of calving class): 1 - for calves born between 4 hours and 7 hours; 2 - between 8 hours and 10 hours; 3 - between 11 hours and $13 \mathrm{~h} ; 4$ - between 14 hours and 15 hours; 5 - between 16 hours and 18 hours and, finally, 6 - between 18 hours and 23 hours;

CTAT (feeding obstacle class): 1 - obstacles and 2 - no obstacles.

For PN variables (in $\mathrm{kg}$ ), TP (in minutes), TPTM (in minutes) and $\mathrm{P} 120$ (in $\mathrm{kg}$ ), variance analysis was done (ANOVA), using the version 9.1 statistical program (7), as well as measurement estimates, minimum and maximum values with their respective standard deviations, and finally, error calculation of these variables. After this analysis the $\mathrm{F}$ Test was applied at a level of $5 \%$ probability for comparing averages, in order to detect differences present in the $\mathrm{F}$ Test in both breeds (Nelore y Guzerat) for TP, TPTM, P120.

The TCC variable was classified as follows:

1 - for calved cows that maintained contact from 0 to $20 \%$;

2 - from 20 to $40 \%$;

3 - from 40 to $60 \%$;

4 - from 60 to $80 \%$ and

5 - above $80 \%$.

These percentages were determined from the total observed time versus the time that the cow was in contact with the calf.

\section{RESULTS}

Regarding the weight and mortality of calves (Figure 1), there was a greater frequency of representativo de la latencia para ponerse de pie (TP), así como también, de la latencia para intentar mamar después de ponerse de pie (TPTM).

Análisis estadístico. Fueron definidos dos conjuntos de variables: uno para el comportamiento de los terneros y la ganancia de peso de los mismos a los 120 días de edad, y otro para el comportamiento de las vacas junto con los terneros.

Para los terneros fueron consideradas cuatro variables:

Tiempo para ponerse de pie (TP). Tiempo que el ternero llevó desde el nacimiento hasta permanecer apoyado en los cuatro miembros, de manera firme o no equilibrado;

Tiempo para intentar mamar después de ponerse de pie (TPTM). Definido como el tiempo que el ternero ha llevado después de quedarse de pie para iniciar el intento de sostenerse en la ubre; Peso al nacer (PN). Peso del ternero al día siguiente del nacimiento;

Peso a los 120 días (P120). Peso del ternero a los 120 días de vida.

Para las vacas, la variable fue:

Tiempo de contacto con la cría (TCC). Definida como el porcentaje del tiempo en que la vaca estuvo en contacto con la cría en relación al tiempo total de observación, en actividades como lamer, oler, tocar el ternero, cuidando e incentivando los movimientos de los terneros.

Los valores obtenidos en campo fueron agrupados en clases (de 1 a 6 , diferentemente), de las cuales fueron originadas las siguientes variables independientes:

CPN (clase peso al nacimiento): 1 - para terneros de 25 a $30 \mathrm{~kg}, 2$ de 31 a $35 \mathrm{~kg}$ y 3 de 36 a $40 \mathrm{~kg}$;

CNP (clase números de partos): 1 - primer parto, 2 - segundo parto y 3 - tercer parto en adelante;

CLPR (clase local de parto en relación al rebaño): 1 - para partos distantes de 0 a 10 metros del rebaño , 2 - para partos de 11 a $30 \mathrm{~m}$ y 3 - para partos arriba de $30 \mathrm{~m}$;

CHP (clase hora del parto): 1 - para terneros nacidos entre las $4 \mathrm{~h}$ y las $7 \mathrm{~h} ; 2$ - entre las $8 \mathrm{~h}$ y las $10 \mathrm{~h} ; 3$ - entre las $11 \mathrm{~h}$ y las $13 \mathrm{~h} ; 4$ - entre las $14 \mathrm{~h}$ y las $15 \mathrm{~h} ; 5$ - entre las $16 \mathrm{~h}$ y las $18 \mathrm{hy}$, finalmente, 6 - entre las $18 \mathrm{~h}$ y las $23 \mathrm{~h}$;

CTAT (clase obstaculización de mamada): 1 - obstaculiza y 2 - no obstaculiza.

Para las variables PN (en $\mathrm{kg}$ ), TP (en minutos), TPTM (en minutos) y P120 (en $\mathrm{kg}$ ) fueron 
calves with intermediate weights ( 31 to $35 \mathrm{~kg}$ ), indicating the absence of mortality in the entire analyzed herd ( $0 \%$ for the two breeds).

It was observed that approximately $80 \%$ of the cows had multiple births. This fact made comparing the results of both analyzed breeds easier.

In relation to CTAT, approximately $90 \%$ of Nelore cows did not impede their calves when these tried to feed while $20 \%$ of Guzerat cows created some obstacles when their calves tried to feed (Figure 2).

In this study, it can be observed that more than $55 \%$ of Nelore cows calved at night (between 18 hours and 23 hours) while with the Guzerat cows $(60 \%)$ calving was distributed in the first two classes (class 1 - between 4 hours and 7 hours and class 2 - between 8 hours and 10 hours) coinciding with the results found by Toledo (8) for positive TP correlation, where probably better temperatures and air humidity helped improve imprinting.

In this investigation it was possible to observe that the TPR value was superior in Guzerat cows, where $80 \%$ of them gave birth at a minimum distance of $30 \mathrm{~m}$ from the flock (Figure 3 ).

Results presented in table 1 show significant values for the studied TP, TPTM and P120 variables, where the Nelore cows were outstanding in comparison to the Guzerat breed.

Table 1. Average values of the variables (PN: Birth weight; TP: Time to stand; TPTM: Time to feed after standing; P120: Weight at 120 days; TCC: Time in contact with calf), found in the two breeds observed.

\begin{tabular}{cccccc}
\hline Breeds & $\begin{array}{c}\text { PN } \\
(\mathbf{K g})\end{array}$ & $\begin{array}{c}\text { TP } \\
\text { (min.) }\end{array}$ & $\begin{array}{c}\text { TPTM } \\
(\mathbf{m i n} .)\end{array}$ & $\begin{array}{c}\text { P120 } \\
\mathbf{( K g )}\end{array}$ & TCC \\
\hline Nelore & $33^{\mathrm{a}}$ & $71^{\mathrm{a}}$ & $39^{\mathrm{a}}$ & $122^{\mathrm{a}}$ & $4^{\mathrm{a}}$ \\
Guzerat & $33^{\mathrm{a}}$ & $153^{\mathrm{b}}$ & $114^{\mathrm{b}}$ & $109^{\mathrm{b}}$ & $3^{\mathrm{a}}$ \\
\hline \multicolumn{7}{l}{ The average followed by the same letter does not differ statistically, }
\end{tabular}
using the F Test, $\mathrm{p}<0.05$.

Average TP values of 71.22 and 153 minutes were found for the Nelore and Guzerat breeds, respectively. Considering this variable, some Nelore cows presented minimum values of 28 minutes, while the values were 67 minutes for the Guzerat cows (Table 2). This information was also obtained by Toledo (8) and Schmidek et al (4).

In table 2 the Guzerat cows presented minimum and maximum TPTM values of 34 and 315 realizados análisis de variancia (ANOVA), utilizando el programa estadístico SAS, versión 9.1 (7), así como estimadas las medias, los valores de máximo y mínimo, con sus respectivos desvíos estándar y, finalmente, fue calculado el error de estas variables. Después de este análisis fue aplicado el Test $\mathrm{F}$ al nivel de un $5 \%$ de probabilidad para la comparación de promedios, con el fin de detectar las diferencias presentadas en el Test de $\mathrm{F}$ en ambas razas (Nelore y Guzerat), para TP, TPTM, P120.

La variable TCC fue clasificada en clases:

1 - para vacas paridas que mantuvieron contacto de 0 a $20 \%$;

2 - de 20 a $40 \%$;

3 - de 40 a $60 \%$;

4 - de 60 a $80 \%$ y

5 - arriba de $80 \%$.

Estos porcentajes fueron determinados a partir de la relación del tiempo total observado versus el tiempo en que la vaca estuvo en contacto con la cría.

\section{RESULTADOS}

Con relación al peso y mortalidad de terneros (Figura 1), se obtuvo una mayor frecuencia de nacimientos con pesos intermedios ( $31 \mathrm{a} 35 \mathrm{~kg}$ ), indicando ausencia de mortalidad en todo el rebaño analizado ( $0 \%$ para las dos razas).

Fue posible observar que aproximadamente el $80 \%$ de las vacas fueron multíparas. Este hecho facilitó la comparación de los resultados para ambas razas analizadas.

Con relación a CTAT, aproximadamente el 90\% de las vacas Nelore no impidieron a sus terneros cuando estos intentaban mamar y el $20 \%$ de las vacas Guzerat crearon algunos obstáculos para que sus crías intentaran mamar (Figura 2).

En el presente trabajo, se puede observar que más del $55 \%$ de las vacas Nelore parieron en el período nocturno (entre las $18 \mathrm{~h}$ y las $23 \mathrm{~h}$ ), mientras que en las vacas Guzerat (60\%) los nacimientos se distribuyeron en las dos primeras clases (clase 1entre las $4 \mathrm{~h}$ y las $7 \mathrm{~h}$ y clase $2-$ entre las $8 \mathrm{~h}$ y las $10 \mathrm{~h}$ ), coincidiendo con los resultados encontrados por Toledo (8), con los mismos resultados de correlación positiva para TP, donde probablemente las temperaturas más amenas y la humedad del aire pudieron mejorar el "imprinting", o impronta.

En esta investigación fue posible observar que el valor de la TPR fue superior en las vacas Guzerat, donde el $80 \%$ de ellas parieron a una distancia mínima de 30 m con relación al rebaño (Figura 3). 


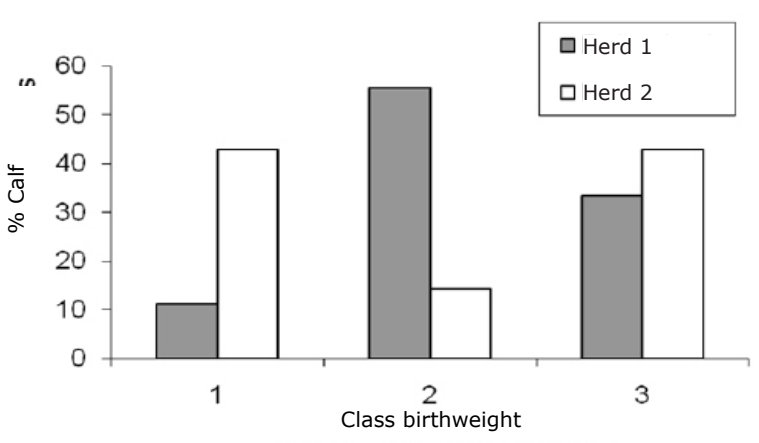

Figure 1. CPN values ( $1-25$ to $30 \mathrm{~kg}, 2-31$ to $35 \mathrm{~kg}$ and $3-36$ to $40 \mathrm{~kg}$ ), in percentages for the two breeds analyzed.

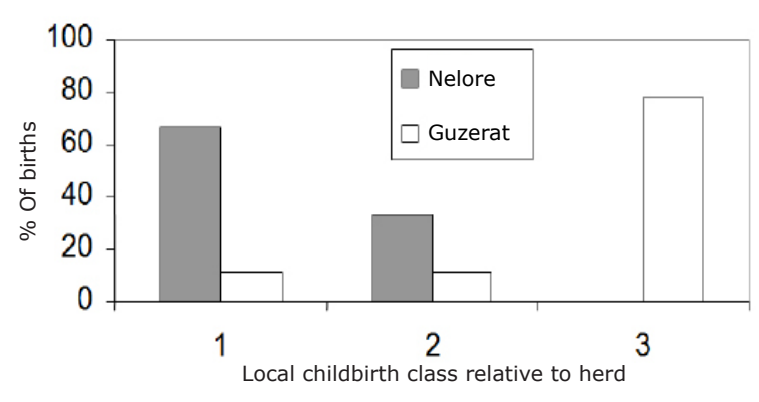

Figure 3. TPR values ( 1 - for births at a distance from 0 to $10 \mathrm{~m} ; 2$ - from 11 to $30 \mathrm{~m} ; 3$ - above $30 \mathrm{~m}$ ), in percentages for the two analyzed breeds.

Table 2. Average, standard deviation (de), average, maximum and minimum values for the characteristics (PN: Weight at birth; TP: Time to stand up; TPTM: Time to feed after standing up; P120: Weight at 120 days; TCC: Time in contact with calf), presented significant results regarding the analyzed breeds.

\begin{tabular}{cccccc}
\hline Characteristic & Average & DE & \multicolumn{4}{c}{ Average Minimum Maximum } \\
\hline TP (min.) & & & & & \\
Nelore & $71^{\text {a }}$ & 33.38 & 73.5 & 28 & 119 \\
Guzerat & $153^{\text {b }}$ & 98.62 & 102.42 & 67 & 315 \\
TPTM (min.) & & & & & \\
Nelore & $39^{\text {a }}$ & 11.39 & 39.00 & 21 & 53 \\
Guzerat & $114^{\text {b }}$ & 114.76 & 74.14 & 34 & 315 \\
P120 (kg) & & & & & \\
Nelore & $122^{\text {a }}$ & 7.35 & 124.12 & 109 & 131 \\
Guzerat & $109^{\circ}$ & 11.23 & 110.75 & 86 & 122 \\
\hline
\end{tabular}

The average followed by the same letter does not differ statistically, using the F Test $F, p<0.05$

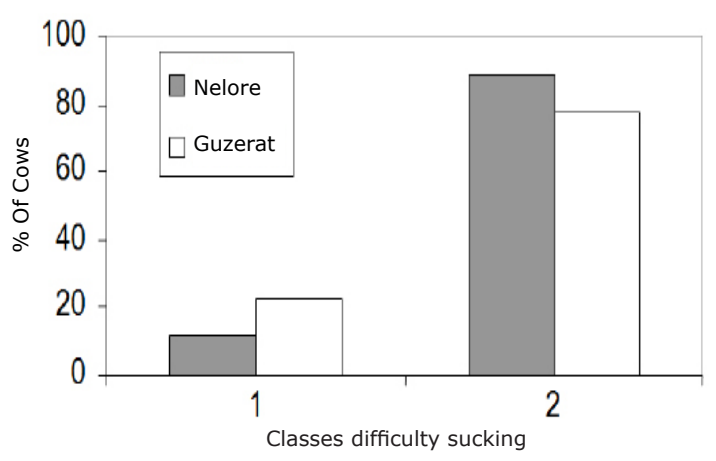

Figure 2. CTAT values (1 - difficulty to feed, 2 - no difficulty to feed), in percentages for the two analyzed breeds.

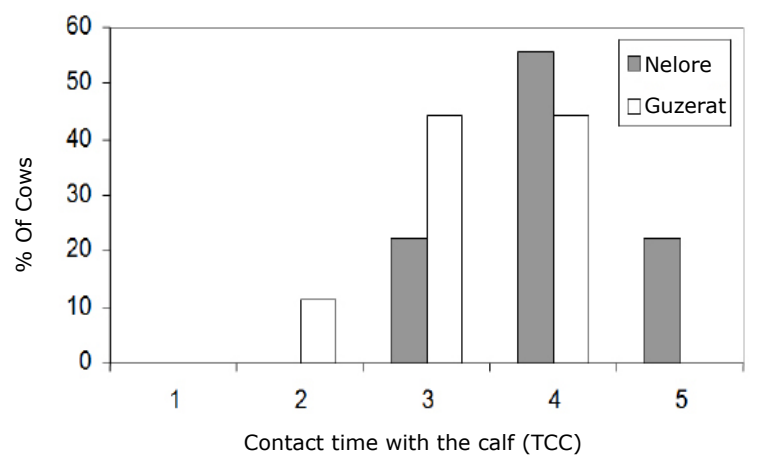

Figure 4. TCC values ( 1 - for cows that had contact from 0 to $20 \% ; 2-20$ to $40 \% ; 3-40$ to $60 \% ; 4-60$ to $80 \%$; 5 - more than $80 \%$ ), for the two analyzed breeds.

Los resultados presentados en la tabla 1 muestran valores significativos para las variables estudiadas TP, TPTM y P120, donde las vacas Nelore se sobresalieron con relación a las de la raza Guzerat.

En el estudio fueron encontrados valores promedios de TP de 71.22 y de 153 minutos para las razas Nelore y Guzerat, respectivamente. Considerando esta variable, algunas vacas Nelore presentaron valores mínimos de 28 minutos, mientras que en las Guzerat dichos valores fueron de 67 minutos (Tabla 2). Estas mismas informaciones también fueron obtenidas por Toledo (8) y Schmidek et al (4).

En la tabla 2 se observa que las vacas Guzerat presentaron para la variable, valores mínimos y máximos de TPTM de 34 y de 315 minutos, respectivamente. Estos valores posiblemente están asociados a la agitación de las vacas, las mismas que dificultan el comportamiento del ternero. Como se puede observar en la misma tabla, los datos de las vacas Nelore también mostraron valores significativos para esta variable (mínimo de 21 y máximo de 53 minutos). Se deduce que pueda existir una asociación entre TP, con valores promedios de 71 minutos para los animales Nelore 
minutes, respectively, for this variable. These values are possibly associated with the cow's agitation, which affects the behavior of the calf. As can be observed in the same table, data on Nelore cows also showed significant values for this variable (minimum 21 and maximum 53 minutes). It is deduced that an association could exist between TP, with average values of 71 minutes for Nelore animals and 153 minutes for Guzerat and TPTM animals, with average values of 39 minutes for Nelore cows and 114 minutes for Guzerat. The TCC variable (Figure 4 ) is numerically superior in Nelore cows, with class 3 variations (those that maintained 40 to $60 \%$ contact with the calves) up to class 5 (with $80 \%$ contact).

Regarding the weight of the animals, values found in the study show the significant effect of the abovementioned variables (TP, TPTM) in connection with P120, confirming the maternal ability of the Nelore cows to birth calves that are heavier at 120 days. The average values were $122 \mathrm{~kg}$ and the standard deviation 7.35, while the Guzerat breed presented an average weight of $109 \mathrm{~kg}$ and a standard deviation of 11.23. The TCC variable, in spite of having presented greater values for Nelore cows, was not significant.

\section{DISCUSSION}

Keeping in mind the calvings, questions arise concerning aspects such as: weight, calf behavior, cow behavior, birth hour, among others. The affirmation is that lighter calves perform better, have easier births, and avoid distocic or difficult births. However, studies have revealed that lighter weight calves with below average indexes present slower behavior, higher mortality index, more lactation difficulties $(60 \%)$, and also higher TP (4).

Cows recognizing calves, an increase in the number of births and the age of the cow all acquire a positive correlation with parental commitment (8).

The first moments a cow has with her calf are fundamentally important, generating an experience for both (9). This characteristic has a direct influence on the calf's survival, since feeding time and colostrum quality could be compromised. Its ingestion is essential, since it contains proteins, casein, vitamins, minerals and immunoglobulins that will play a physiological and functional role in the neonatal development $(8,10)$. y 153 minutos para los de la raza Guzerat y TPTM, con valores promedios de 39 minutos para las vacas Nelore y 114 minutos para las Guzerat. Con relación a la variable TCC (Figura 4), ésta se mostró numéricamente superior en las vacas Nelore, ocurriendo variaciones de la clase 3 (las que mantuvieron de un 40 a un $60 \%$ de contacto con la cría) hasta la clase 5 (con un $80 \%$ de contacto).

Con relación al peso de los animales, los valores encontrados en el trabajo demuestran el efecto significativo de las variables antes citadas (TP, TPTM) con relación al P120, confirmando la habilidad materna de las vacas Nelore en criar terneros más pesados a los 120 días. Sus valores promedios fueron de $122 \mathrm{~kg}$ y el desvío estándar de 7.35, mientras que los de la raza Guzerat presentaron un peso promedio de $109 \mathrm{~kg}$ y desvío estándar de 11.23. La variable TCC, a pesar de haber presentado mayores valores para las vacas Nelore, no fue significativa.

\section{DISCUSIÓN}

Tomando en consideración los nacimientos de los terneros, surgen dudas sobre algunos aspectos, tales como: peso, comportamiento de los terneros, de sus madres, hora de su nacimiento, entre otros. Es común la afirmación de que terneros livianos presentan mejores desempeños, provocando partos más fáciles, evitando partos distócicos o laboriosos. Sin embargo, los estudios han revelado que terneros poco pesados, con índices abajo de la media, presentan comportamientos más lentos, mayores índices de mortalidad, mayores índices de fallas en la lactación $(60 \%)$, repitiéndose también en mayores TP (4).

El reconocimiento de la cría por la madre, el aumento del número de partos y la edad de la vaca, adquieren una correlación positiva para el compromiso de parentesco (8).

Los primeros instantes de la vaca con el ternero son de fundamental importancia, generando la experiencia de ambos (9). Esa característica posee influencia directa en la supervivencia del ternero, pues aumenta el tiempo para mamar y la calidad del calostro puede estar comprometida. Su ingestión es imprescindible, pues contiene proteínas, caseína, vitaminas, minerales, y principalmente las inmunoglobulinas que actuarán en el desarrollo fisiológico y funcional de los neonatos $(8,10)$.

Las vacas poseen una característica peculiar con relación al horario de parto. Los estudios de Schmidek (4) y Toledo (8) informan que es posible observar un gran número de los mismos, ocurriendo en las horas más frescas del día, como en los horarios nocturnos, ocasionando sensación de confort térmico y muchas 
Cows develop peculiar characteristics when calving. Studies done by Schmidek (4) and Toledo (8) report that many can be observed during the cool hours of the day and at night, giving a sensation of thermic comfort and often of tranquility and safety, and result in more births at these times.

Regarding calving location related to distance from the herd, two extremely important periods must be kept in mind: the acknowledgment period, or response capacity (when pregnant animals are attracted to cows giving birth) and the selectivity period (when interference in the behavior of cow and calf can occur). Also, the farther the calving occurs with relation to the herd, greater is the performance of mother and calf (5).

According to literature (8), calving that occurs at a minimum distance of $30 \mathrm{~m}$ from the herd is satisfactory when considering the relation between the distance from the herd and the time the cows dedicate to the calves. However, this relationship was not observed in Guzerat cows, who presented lower TCC values.

The time to stand is a determining behavior for good bovine performance, and the success of this variable will have optimum results, including locating the udder and the first feeding. It is interesting to highlight that the care and experience of the cow will be decisive, since these activities help regulate body temperature, avoiding hypothermia and activating blood circulation, breathing and the motor and sensorial system (11-14).

Contact between the cow and the calf begin in the moments before birth begins with mechanical stimulus such as the dilatation of the cervix to facilitate the birth of the calf (1). These stimuli can possibly result in the cow's search to have greater contact with the calf, affecting the agility of the newborn, since greater contact means that the calf will stand quicker and it is hoped that it will try to feed quicker, thus lowering TPTM values. This variable, along with TP, could also show the newborn's strength.

To select animals for improvement, some evaluation criteria must be followed, since genetic evaluation is one of the most important tools presently used (15). Within those criteria the most outstanding is: weight at 120 days (P120), which has a direct correlation with maternal ability, determining a connection between the cow's performance and the growth of the calf $(6,10)$. veces tranquilidad y seguridad, favoreciendo la concentración de pariciones en esas horas.

Tratándose de la localización del parto con relación a la distancia del rebaño, hay que tomar en consideración dos períodos extremamente importantes: el período del reconocimiento, o capacidad de respuesta (cuando ocurre atracción de animales gestantes por vacas parturientas) y el período de selectividad (cuando puede ocurrir interferencia en el comportamiento de la madre y de su cría). Así, cuanto más distante ocurra el parto con relación al rebaño, mejor será el desempeño de la madre y su ternero (5).

Según la literatura (8), la ocurrencia del parto a una distancia mínima de $30 \mathrm{~m}$ del rebaño es satisfactorio cuando se observa una relación entre la distancia del rebaño y el tiempo que estas madres dedican a las crías. No obstante, esta relación no fue observada en las vacas Guzerat que presentaron los menores valores de TCC.

Considerando que el tiempo para ponerse de pie es un comportamiento determinante para el buen desempeño del bovino, el éxito de esta variable desencadenará resultados óptimos en otras actividades, tales como localizar las ubres y realizar la primera mamada. Es interesante resaltar que el cuidado y experiencia de la madre serán decisivos, pues estas actitudes ayudan a la manutención de la temperatura corporal, no permitiendo que la cría sufra una hipotermia, sino que ocurra en la activación de la circulación sanguínea y respiratoria y activación del sistema motor y sensorial (11-14).

El contacto de la madre con su cría se desencadena en los instantes que anteceden al parto, a través de estímulos mecánicos, como la dilatación del cérvix para facilitar el paso del ternero (1). Estos estímulos posiblemente lograrán que la madre busque tener un mayor contacto con la cría, influyendo en la agilidad del neonato, pues cuanto mayor el contacto, más rápido el ternero se levantará y se espera también que intente mamar más rápidamente, para de esta manera conseguir que se obtengan valores menores de TPTM. Esta variable, conjuntamente con la TP, podrá también caracterizar el vigor del recién nacido.

Para seleccionar animales con miras al mejoramiento, se necesita seguir algunos criterios de evaluación, siendo la evaluación genética una de las herramientas más importantes usadas actualmente (15). Entre tales criterios, el que más se destaca es: el peso a los 120 días (P120), donde el mismo tiene correlación directa con la habilidad materna, determinando la preferencia por el desempeño de la vaca con el crecimiento del ternero $(6,10)$. 
Lira et al (16) suggest giving greater attention and selection to animals with greater preweaning weight, since it is the period of life when the animal grows and develops quicker, contributing to the reduction of production costs at that age.

This variable ( $P 120)$ is one of the most important to be analyzed, since it influences TP, TPTM and TCC variables (17). The variable (P120) will reflect characteristics such as weight at 18 months, precocity and canal performance.

Maternal behavior observed showed superiority in the Nelore breed, especially in TP, TPTM and P120 variables.

Studies can contribute to minimize production costs, as well as using rational handling techniques oriented to increasing the weight of the calves and promoting herd improvement.
Lira et al (16) sugieren mayor atención y selección en los animales con mayor potencial para pesos predestete, pues es el período de la vida en el cual el animal presenta mayor velocidad de crecimiento y desarrollo, contribuyendo con reducción en los costos de producción en la edad de aprovechamiento.

Esta variable (P120) es una de las más importantes a ser analizadas, pues sufre influencia de las variables TP, TPTM y TCC (17). La variable (P120) reflejará en características como peso a los 18 meses, precocidad y rendimiento de la canal.

Los comportamientos maternales observados demostraron una superioridad para la raza Nelore, especialmente en las variables TP, TPTM y P120.

Los estudios pueden contribuir para minimizar los costos de producción, conjuntamente con la utilización de técnicas de manejo racionales, orientadas a aumentar el peso de los terneros y promover el mejoramiento del rebaño.

\section{REFERENCES}

1. Hötzel MJ, Machado Filho LCP. Bem-estar Animal na Agricultura do Século XXI. Rev Etol 2004; 6(1):03-15.

2. Paranhos da Costa MJR, Albuquerque LG, Eler JP, Silva JAII V. Suckling behaviour of Nelore, Gir and Caracu calves and their crosses. Appl Anim Behav Sci 2006; 101:276-287.

3. Toledo, LM. Fatores intervenientes no comportamento de vacas e bezerros do parto até a primeira mamada [Tese Doutorado]. Jaboticabal, Brasil: Universidade Estadual Paulista. Faculdade de Ciências Agrárias e Veterinárias; 2005.

4. Schmidek A, Mercadante MEZ, Paranhos da Costa MJR, Razook AG, Figueiredo LA. Falha na primeira mamada em bezerros Guzerat: fatores predisponentes e parâmetros genéticos. Rev Bras de Zootec 2008; 37(6):998-1004.

5. Paranhos da Costa MJR, Schmidek A, Toledo LM. Relações materno-filiais em bovinos de corte do nascimento à desmama. Mother-offspring interactions in beef cattle from birth to weaning. Rev Bras Reprod Anim 2007; 31:183-189.

6. SchmidekA, Paranhos da Costa MJR, Albuquerque LG, Toledo LM. Genetic aspects of vigour and maternal ability for Nelore and Guzerat breeds. Rev Etol 2003; 5:206.
7. SAS. Statistical Analysis System - SAS Version 9.0, 13th ed. Cary: Statistical Analysis System Institute; 2004.

8. Toledo, LM. Fatores intervenientes no comportamento de vacas e bezerros do parto até a primeira mamada [Tese Doutorado]. Brasil, Jaboticabal: Universidade Estadual Paulista, Faculdade de Ciências Agrárias e Veterinárias; 2005.

9. Broom M, Molento CFM. Bem estar animal: conceito e questões relacionadas- Revisão. Arch of Vet Sci 2004; 9(9):1-11.

10. Souza EA, Andrea MV, Santos CS, Paranhos da Costa MJR, Bittencourt TCBSC, Marcondes CR. Relações materno filiais e sua influencia no peso pré desmama de animais Nelore da Bahia. Arch Zootec 2009; 58(224):729-732.

11. Machado Neto R, Faroni CE, Pauletti P, Bessi R. Levantamento do manejo de bovinos leiteiros recém nascidos: desempenho e aquisição de proteção passiva. Rev Bras Zootec 2004; 33(6):2323-2329.

12. Machado TMP. Comportamentos afiliativos em vacas leiteiras a pasto, o papel da lambida [Tese Mestrado]. Florianópolis, Brasil: Universidade Federal de Santa Catarina, Centro de Ciências Agrárias; 2009. 
13. Grandinson K. Genetic background of maternal behaviour and its relation to offspring survival. Livest Prod Sci 2005; 93:43-50.

14. Everett-Hincks JM, Lopez-Villalobos N, Blair $H T$, Stafford KJ. The effect of ewe maternal behaviour score on lamb and litter survival. Livest Prod Sci 2005; 93:51-61.

15. Madella-Oliveira AF, Quirino CR, Fonseca FA. Análise da genética do comportamento em animais de produção. Pubvet 2011; 5(12):1-13.
16. Lira TS, Pereira LS, Lopes FB, Ferreira JL, Lôbo RB, Santos GCJ. Tendências genéticas para características de crescimento em rebanhos Nelore criados na região do Trópico Úmido do Brasil. Ci Anim Bras 2013; 14(1):23-31.

17. Kippert CJ, Rorato PRN, Campos LT, Boligon AA, Weber T, Gheller DG, Lopes JS. Efeito de fatores ambientais sobre escores de avaliação visual à desmama e estimativa do parâmetro genéticos, para bezerros da raça charolês. Ciênc Rural 2006; 36(2):579-585. 